\title{
Pharmacogenetics of bisphosphonate-associated osteonecrosis of the jaw (ONJ)
}

\section{Fung PPL, ${ }^{1}$ Nicoletti $P,{ }^{2}$ Shen $Y,{ }^{3}$ Porter $S,{ }^{4}$ Fedele $S^{5}$}

${ }^{1}$ BDS, MSc, PhD, University College London, UCL Eastman Dental Institute, 256 Gray's Inn Road, WC1X 8LD London, UK

${ }^{2} \mathrm{MD}, \mathrm{PhD}$, Department of Systems Biology, Columbia University, Irving Cancer Research Center, 1130 St. Nicholas Avenue, New York, NY 10032

${ }^{3} \mathrm{MD}, \mathrm{PhD}$, Department of Systems Biology, Columbia University and Department of Biomedical Informatics, Columbia University, Irving Cancer Research Center, 1130 St. Nicholas Avenue, New York, NY 10032.

${ }^{4} \mathrm{MD}, \mathrm{PhD}$, FDS RCS, FDS RCSE, University College London, UCL Eastman Dental Institute, 256 Gray's Inn Road, WC1X 8LD London, UK

${ }^{5}$ DDS, PhD, University College London, UCL Eastman Dental Institute, 256 Gray's Inn Road, WC1X 8LD London, UK and NIHR University College London Hospitals, Biomedical Research Centre, London, UK. 


\section{Keywords}

- Jaw osteonecrosis

- Bisphosphonates

- Pharmacogenetics

- Pharmacogenomics

- Genes

- Single nucleotide polymorphisms

\section{Key points}

- Jaw osteonecrosis (ONJ) develops in a small subgroup of individuals exposed to bisphosphonate medications.

- Although a number of associated clinical risk factors have been identified, it remains difficult to predict which individuals will eventually develop ONJ.

- Pharmacogenetics has the potential to identify genetic variants associated with an increased risk (susceptibility) of developing ONJ.

- A number of genome wide association and candidate gene studies have been performed during the last few years; however they are limited by small cohort size and lack of robust genomic statistical significance.

- The study of genetic susceptibility to ONJ requires international multicentre collaborative networks and larger and better phenotyped cohorts.

\section{Disclosure}

The authors have nothing to disclose. 


\section{Synopsis/Abstract}

Osteonecrosis of the jaws (ONJ) is a potentially severe disorder that develops in a subgroup of individuals who use or have used bisphosphonate medications (BP). A number of clinical risk factors have been associated with the risk of ONJ development, however evidence is limited and in most instances ONJ remains an unpredictable ADR. Inter-individual genetic variability can contribute to explaining ONJ development in a subset of BP users and the discovery of relevant associated gene variants could lead to the identification of individuals at higher risk. A number of small pharmacogenetic studies have been performed during the last few years but no genetic variant has been found to be robustly associated with the susceptibility to ONJ. 


\section{Introduction}

Bisphosphonates (BPs) are anti-resorptive agents commonly used in treatment of osteoporosis, multiple myeloma and bone metastases from solid cancers [1]. BPs are internalised into osteoclasts via endocytosis and result in the inhibition of osteoclast activity through different mechanisms [2, 3]. Nitrogen-containing BPs, including alendronate, ibandronate, risedronate, pamidronate and zoledronate, inhibit farnesyl pyrophosphate synthase, a key enzyme of the mevalonate pathway. This (i) prevents prenylation of guanosine triphosphatase (GTPase), which is essential for osteoclast function and survival, and (ii) causes accumulation of isopentenyl diphosphate, which in turn can induce osteoclast apoptosis [4]. Nonnitrogen-containing BPs, including clodronate and etidronate, are incorporated into adenosine triphosphate (ATP) analogue, which can also induce osteoclast apoptosis [5].

BPs are associated with a potentially severe adverse drug reaction (ADR): osteonecrosis of the jaw (ONJ), which was initially reported in 2003 [6]. Since then, thousands of ONJ cases have been reported worldwide [7]. ONJ is characterised by the development of jawbone necrosis and is traditionally presented with areas of exposed necrotic jawbone through mucosal or facial skin fenestrations ranging from a few millimetres to several centimetres [8-10]. More recent studies have reported that in approximately $25 \%$ of cases ONJ can also present without soft tissue fenestration (non-exposed variant), with affected patients showing otherwise unexplained painful symptoms, intra-oral or extra-oral fistulae, tooth mobility or tooth loss, sinusitis or mandibular facture [1, 11-13]. Both the exposed and non-exposed variants of ONJ can present with extensive necrosis, secondary infection and severe pain [14], therefore causing a significant reduction in the quality of life [15]. Figures 
on ONJ prevalence and incidence vary widely and remain controversial. Available data suggests that $\mathrm{ONJ}$ develops in a subgroup of individuals who use or have used BPs: approximately 7\% among those using intravenous BPs for cancer management and $0.12 \%$ of those who take oral BPs due to osteoporosis [16]. Little robust information is available regarding $\mathrm{ONJ}$ aetiopathogenesis; similarly, it is unclear why ONJ develops only in a subset of patients [17-18]. A number of clinical risk factors have been associated with ONJ development, including underlying malignant disease, use of intravenous high-potency BPs, high dose or long-term BP therapy, use of concomitant medications, dental infections and surgical procedures to the jawbones [19]. Nevertheless, relevant literature lacks robustness and consistency, and in most instances ONJ remains an unpredictable ADR.

Inter-individual genetic variants are known to potentially determine disparate response to medications, including toxicity. It was estimated that genetic variability could contribute to ADR development in more than half of the medications examined in a systematic review [20]. Inter-individual genetic variability can therefore contribute to explaining ONJ development in a subset of individuals using BPs. In the past few years, a number of small studies investigated the potential association of ONJ development with genetic factors [21-31]. The aim of the present study is to provide a critical and comprehensive review on available evidence regarding pharmacogenetics of ONJ.

\section{Pharmacogenetics and adverse drug reactions (ADRs)}

By definition, pharmacogenetics is the study of how genetic differences influence the variability in patients' responses to drugs, including toxicity [32]. Examples of genetic factors contributing to individuals' susceptibility to ADR include $H L A-A * 31: 01$ for 
carbamazepine (CMZ)-induced skin reactions in Europeans [33], $H L A-B^{\star} 15: 02$ for CMZ-induced Stevens-Johnson syndrome in Asians [34], SLCO1B1 for statininduced myopathy [35], and $H L A-B^{\star} 57: 01$ for abacavir-induced hypersensitivity reactions [36-37], as well as for flucloxacillin-induced liver injury [38]. In the majority of cases, the genetic risk variants are drug-specific (one or a few medications) and population (ethnicity)-specific [33, 34, 39]. Among the drug-induced liver injuries (DILI), $H L A-B^{*} 57: 01$ is only known to be associated with flucloxacillin-induced reactions, while $H L A-D R B 1^{*} 15: 01$ is known to be associated with both amoxicillinclavulanate [39] and lumiracoxib [40]. Examples of successful and cost-effective translation of pharmacogenetic data into clinical practice include $H L A-B{ }^{\star} 57: 01$ screening prior to initiating treatment with abacavir and $H L A-B^{*} 15: 02$ screening prior to $\mathrm{CMZ}$ therapy in Asians, both recommended by the Food and Drug Administration (FDA) [41-42]. With such robust and growing evidence, pharmacogenetics is becoming a realistic mean to tailor and personalise safe and effective therapy for single individuals [43]. Pharmacogenetic studies comprise genome-wide association studies (GWAS) and candidate gene studies [44]. A total of two GWAS and nine candidate gene studies have been performed in relation to ONJ.

\section{GWAS on ONJ}

GWAS is a comprehensive research approach that is useful for investigating both complex disease and drug response including ADR. Typically, a GWAS screens millions of single nucleotide polymorphisms (SNPs) across the entire genome, in which a SNP refers to a single-base difference in DNA sequence present in at least $1 \%$ of the general population [45]. The large set of SNPs, which form part of a standard GWAS genotyping chip, have been chosen based on their property of 
being proxies to others within the same genomic region; this is known as linkage disequilibrium or LD [46]. A successful GWAS relies on a reasonably complete coverage of genetic variants, which include SNPs that are actually typed with a chip, as well as SNPs that have not been typed but can be predicted through LD. In other words, a causal variant can be a typed SNP, or an untyped one with a typed proxy SNP. In the latter case, "fine-mapping" studies should follow so as to search for the untyped causal variant in the same genomic region. GWAS usually have casecontrol design and a SNP is identified as a risk factor if the frequency of its minor allele in the cases is significantly different than the controls. Because GWAS test millions of SNPs, it is possible that some variants are identified as having high frequency and very small $p$-values simply by chance; in order to avoid these false positives, a stringent statistical correction for multiple comparisons is commonly required, which is known as Bonferroni correction. Instead of the usual $p<0.05$, the significance level for GWAS is calculated as 0.05 divided by roughly 1 million SNPs, i.e. $p<5 \mathrm{E}-08$ [45].

To date, two GWAS have been conducted on ONJ and relevant results are summarised in Table 1. The first GWAS, also the first pharmacogenetic study on ONJ, was published in 2008 by a Spanish team [21]. They studied 87 pamidronatetreated multiple myeloma patients, who were of Spanish descent, of whom 22 had developed ONJ. These cases were compared with 65 drug-exposed controls who had not developed ONJ after a median follow-up of 64 months. 500,568 SNPs were screened and rs1934951 in CYP2C8 was found to be most significant, although it did not reach genome-wide threshold of significance $(\mathrm{OR}=12.75 ; 95 \% \mathrm{Cl}, 3.7$ to 43.5 ; $p=1.07 \mathrm{E}-06)$. . This study suggest that individuals with this SNP had nearly 13 times greater odds of developing ONJ than those without it. Though not directly affecting 
BPs' metabolism, CYP2C8 is known to be involved in osteoclast inhibition, osteoblast differentiation, and regulation of vascular tone, which may contribute to ONJ development [47].

The second GWAS was published in 2012 and compared 30 zoledronate-treated breast cancer patients who had developed ONJ with 17 drug-exposed controls and 1,726 population controls [28]. The participants were of European descent. Compared to the previous GWAS, 731,442 SNPs were screened. Standard imputation was performed to enrich the genotype dataset, and an imputed SNP, rs17024608 in RBMS3, was found to be associated with ONJ, with borderline genome-wide significance $(\mathrm{OR}=5.8 ; 95 \% \mathrm{Cl}, 3.0$ to $11.0 ; p=7.47 \mathrm{E}-08)$. The rs17024608 carriers had approximately 6 times higher odds of developing ONJ than the non-carriers. RBMS3 is a gene involved in bone turnover and has been found to be associated with decreased bone mass and osteoporotic fracture [28]. Of note, CYP2C8 variants were not confirmed as risk factors for $\mathrm{ONJ}$ in this cohort of breast cancer patients.

In summary, only two GWAS have been published so far and they suggest that variants in genes CYP2C8 and RBMS3, which are both related to bone turnover, may be associated with ONJ development in multiple myeloma patients of Spanish descent and in breast cancer patients of European descent respectively. There are significant differences between these studies as regards to cohort size, case-control ratio, participants' ethnicity, underlying diseases and BPs type, which hinder meaningful comparison and data pooling. Also, both had relatively small number of cases, which limit their power to detect variants with high relative risk and represent the most likely cause for their failure to identify genome-wide significant variants. Another important aspect of GWAS is the need to replicate results in an independent 
population with similar phenotype, which is considered the gold standard approach so to minimise the risk that potential technical or methodological biases could determine a spurious association signal [48-49]. A small number of candidate gene studies and one meta-analysis aimed at replicating association with rs1934951 in CYP2C8 (detailed below), whereas there remains no attempted replication of rs17024608 in RBMS3.

\section{Candidate gene studies on ONJ}

Similar to GWAS, candidate gene studies often have a case-control design [50]. In general they focus on potentially biologically relevant genes; for ADR, most of the established and high risk genetic risk factors are relevant to drug metabolism or transporters genes [39]. In contrast to GWAS, candidate gene studies screen much fewer variants and do not represent a hypothesis-free approach [51]. They are also prone to methodological weaknesses as they typically have small cohort size, no Bonferroni correction for the $p$-value, and often do not correct for the ethnicity of the cohort. Therefore, it has been suggested that candidate gene design is more suitable for replication studies [52]. A total of nine candidate gene studies on ONJ were published between 2010 and 2013 [22-27, 29-31], including both replication and discovery gene studies.

\section{Replication candidate gene studies}

Four candidate gene studies attempted to replicate the results of the Spanish GWAS [21] through investigating the possible association between rs1934951 in CYP2C8 and ONJ in their respective independent cohorts [22-23, 27, 30] (Table 2). All studies failed to confirm that this variant is significantly associated with the trait ( $p>0.05)$. Paradoxically, Katz et al. [23] and English et al. [22] reported a protective 
OR for this variant. These apparently contradicting results are likely to be related to the design of the replication studies, which failed to investigate populations phenotypically and ethnically similar to that of the original discovery study. In contrast to the first GWAS, none of the four studies included individuals of Spanish descent, although their cohorts consisted mainly of White or Caucasian participants; African Americans were also inappropriately included [22-23]. Also, all four cohorts were predominantly exposed to zoledronate instead of pamidronate. Further, only two replication studies focused on multiple myeloma patients $[23,27]$ whereas one recruited individuals with metastatic prostate cancer [22], and one included individuals with osteoporosis and a wide range of malignant disorders [30]. A recent meta-analysis by Zhong et al. attempted data pooling from the four candidate gene replication studies and the discovery Spanish GWAS [53]. They confirmed that rs 1934951 in CYP2C8 is not associated with ONJ across the whole merged population $(\mathrm{OR}=2.05 ; 95 \% \mathrm{Cl}, 0.67$ to $6.29 ; p=0.2)$, but it might be associated with ONJ development in multiple myeloma patients with a dominant effect $(\mathrm{OR}=5.77$; $95 \% \mathrm{Cl}, 1.21$ to $27.63 ; p=0.03$, combined effect from only two studies [21, 27]). Better-designed studies are required for appropriate replication of rs1934951. There remains no published attempted replication of rs17024608.

\section{Discovery candidate gene studies}

Six discovery candidate gene studies investigated variants in genes other than CYP2C8 and are summarised in Table $3[23-26,29,31]$. These studies analysed the separate and combined effects of variants located in several genes, which had been chosen as they may relate to BPs metabolism and/or ONJ pathogenesis, e.g. bone turnover. Most of them screened only a small number of variants, and had relatively small cohorts, and are therefore susceptible to methodological limitations 
such as inadequate power. Of note, none of the SNPs tested reached the genomewide significance level, i.e. $p<5 \mathrm{E}-08$.

The largest discovery candidate gene study in the literature compared 94 ONJ cases with 110 ethnicity matched BPs-exposed controls [31]. The cohort included individuals with malignant disorders, including multiple myeloma, breast and prostate cancer, who had been exposed mainly to zoledronate or pamidronate. The study hypothesis was that ONJ susceptibility might be linked to the major histocompatibility complex (MHC) class II system, which encodes HLA class II alleles. As mentioned above, HLA alleles are major genetic risk factors for ADRs and are also associated with the adaptive immune system and infection, which in the case of ONJ may be related to the antigen-presenting function of osteoclasts and increased infection and/or inflammation [17]. According to the significance threshold set by the study, two independent $H L A$ haplotypes, $D R B 1{ }^{*} 01 / D R B 1{ }^{*} 15$ and $D Q B 1^{*} 05: 01 / D Q B 1 * 06: 02$, were found to be significantly associated with ONJ development (uncorrected $p \leq 0.05$ ), with $O R>2$. Moreover, the association appeared to be stronger when more than one haplotype were considered together $(\mathrm{OR}=3$; corrected $p=0.0003$ ) [31]. An Italian study by Arduino et al. recruited a population of 30 women with breast cancer or multiple myeloma who had developed zoledronateinduced ONJ cases, 30 drug, gender, disease and ethnicity-matched controls without ONJ, as well as 125 healthy controls [24]. Candidate gene of this study was vascular endothelial growth factor (VEGF), which had been previously reported to be associated with avascular osteonecrosis of the femoral head [54-55]. No statistically significant association was found for any of the three studies SNPs, -634 G>C, +936 C>T, and $-2578 \mathrm{C}>\mathrm{A}(p>0.05)$. However, the haplotype determined by rs2010963 and rs699947 was found to be significantly associated with ONJ (corrected $p=0.02$ ). 
Another Italian study by La Ferla et al. studied 30 zoledronate-induced ONJ cases and 53 zoledronate-exposed controls with multiple myeloma, breast and prostate cancer [29]. Participants were tested for three candidate polymorphisms including one aromatase and two oestrogen receptor polymorphisms, which were selected because of their reported effects upon bone mineral density and remodelling. Results showed that rs10046 (g.132810C>T), a polymorphism in gene CYP19A1, was more prevalent amongst $\mathrm{ONJ}$ cases $(\mathrm{OR}=2.83 ; p=0.04)$. Marini et al. recruited 64 Italian patients with multiple myeloma, breast and prostate cancer who had received zoledronate, 34 of whom developed ONJ [26]. They studied polymorphism rs2297480 in gene FDPS (farnesyl pyrophosphate synthase, a key enzyme of the mevalonate pathway of osteoclasts), which was found to be significantly associated with ONJ ( $p=0.03)$, although not genome-wide significant. This study represents the first attempt to investigate a candidate gene directly involved in BPs mechanism of action. Katz et al. recruited multiple myeloma patients only, including 12 ONJ cases and 66 controls, who were managed with zoledronate and/or pamidronate [23]. In addition to gene CYP2C8, six other candidate genes were studied based on their potential roles in osteoclast genesis and differentiation, bone resorption and bone mineral density. The results showed that, per se, all candidate genes had no effects on ONJ, although a combined genotype of COL1A1, RANK, MMP2, OPG and OPN was significantly associated with $\mathrm{ONJ}$ development $(\mathrm{OR}=1.2 ; 95 \% \mathrm{CI}, 1.8$ to 69.9 ; $p=0.0097)$.

Di Martino et al. studied 1,936 SNPs relevant to 225 genes associated with drug metabolism, disposition and transport in nine multiple myeloma zoledronate-treated patients with ONJ and 10 matched controls [25]. The authors claim that using a platform that interrogates only highly selective SNPs has the advantage of avoiding 
an extremely high number of comparisons, and therefore the need for statistical corrections and large patient cohorts. As a consequence, the study adopted an uncorrected significance level of $p<0.05$ and reported that variants in four genes, PPARG, ABP1, CHST11 and CROT, were statistically significant. However, since nearly 2,000 SNPs were screened, Bonferroni correction was required and the significance threshold should be approximately $2.5 \mathrm{E}-5$ instead, i.e. 0.05 divided by 1,936 [56]. This would mean that, in fact, no SNPs reached the corrected significance threshold. Nonetheless, on the basis of uncorrected results, patients with rs1152003, top SNP in PPARG, had over 30 times higher odds of developing ONJ (OR=31.5; 95\% Cl, 2.35 to 422.32; $p=0.0055)$. Of note, PPARG has also been associated with bone remodelling, bone mass density, as well as angiogenesis [25]. In summary, due to small sample sizes and other methodological limitations, there remains little robust evidence that $\mathrm{ONJ}$ development is associated with any of the candidate SNPs or genes considered in available studies.

\section{Conclusion}

There remain a number of available pharmacogenetic studies on ONJ, which are characterised by relatively small sample sizes and mainly represent candidate gene analyses. Although GWAS are considered more powerful than candidate gene studies due to wider genome coverage and the advantage of being hypothesis-free, there are currently only two GWAS on ONJ phenotype, which only investigated a modest number of cases and have not been appropriately replicated. Overall, no genome-wide significant variant has been robustly associated with the susceptibility to ONJ. In addition to the methodological limitations mentioned above, this may suggests that, if there is any genetic predisposition at all, it may be due to common 
variants with moderate effect size, or rare variants. In the search for genome-wide significant SNPs for ONJ, international multicentre collaborative networks are required in order to study larger and better phenotyped cohorts. 
Table 1. Summary of GWAS

\begin{tabular}{|c|c|c|c|c|c|c|c|c|c|c|c|c|}
\hline Year & Population & $\begin{array}{c}\text { Underlying } \\
\text { disease }\end{array}$ & BPs type & $\begin{array}{c}\text { Case } \\
n\end{array}$ & $\begin{array}{c}\text { Control } \\
n\end{array}$ & Genotyping & SNP & Gene & Chr & $p$-value & OR [95\% Cl] & Ref \\
\hline \multirow{4}{*}{2008} & \multirow{4}{*}{ Spanish } & \multirow{4}{*}{$\begin{array}{c}\text { Multiple } \\
\text { myeloma }\end{array}$} & \multirow{4}{*}{$\begin{array}{l}\text { Majority on } \\
\text { Pamidronate } \\
\text { Zoledronate }\end{array}$} & \multirow{4}{*}{22} & \multirow{4}{*}{$\begin{array}{l}65 \mathrm{BPs} \\
\text { controls }\end{array}$} & \multirow{4}{*}{$\begin{array}{c}\text { Affymetrix } \\
\text { GeneChip } \\
\text { Mapping } \\
500 K \text { set } \\
500,568 \\
\text { SNPs } \\
\text { screened }\end{array}$} & rs1934951 & CYP2C8 & 10 & 1.07E-06 & $\begin{array}{r}12.75[3.7- \\
43.5]\end{array}$ & \multirow{4}{*}{ [21] } \\
\hline & & & & & & & rs1934980 & CYP2C8 & 10 & 4.23E-06 & $\begin{array}{r}13.88 \text { [4.0- } \\
46.7]\end{array}$ & \\
\hline & & & & & & & rs1341162 & CYP2C8 & 10 & $6.22 E-06$ & $\begin{array}{r}13.27 \text { [3.5- } \\
49.9]\end{array}$ & \\
\hline & & & & & & & rs17110453 & CYP2C8 & 10 & $2.15 \mathrm{E}-05$ & $10.2[3.2-32.1]$ & \\
\hline \multirow{13}{*}{2012} & \multirow{13}{*}{$\begin{array}{l}\text { North- } \\
\text { western, } \\
\text { southern, } \\
\text { eastern } \\
\text { European } \\
\text { descent }\end{array}$} & \multirow{13}{*}{$\begin{array}{l}\text { Osteoporosis } \\
\text { Breast } \\
\text { cancer }\end{array}$} & \multirow{13}{*}{$\begin{array}{l}\text { Majority on } \\
\text { Zoledronate }\end{array}$} & \multirow{13}{*}{30} & \multirow{13}{*}{$\begin{array}{c}17 \text { BPs } \\
\text { controls } \\
1,726 \\
\text { population } \\
\text { controls }\end{array}$} & \multirow{13}{*}{$\begin{array}{l}731,442 \\
\text { SNPs } \\
\text { analysed }\end{array}$} & rs17024608 & RBMS3 & 3 & 7.47E-08 & $5.8[3.0-11.0]$ & \multirow{13}{*}{ [28] } \\
\hline & & & & & & & rs5768434 & FAM19A5 & 22 & 1.17E-07 & $12.6[4.9-32.2]$ & \\
\hline & & & & & & & rs11064477 & PHB2 & 12 & $5.16 \mathrm{E}-07$ & $21.7[6.5-71.9]$ & \\
\hline & & & & & & & $12-7016684$ & C1S & 12 & 5.85E-07 & $21.1[6.4-69.8]$ & \\
\hline & & & & & & & $8-58133986$ & IMPAD1 & 8 & $3.10 \mathrm{E}-06$ & $7.3[3.1-16.9]$ & \\
\hline & & & & & & & rs1886629 & KCNT2 & 1 & 5.53E-06 & $3.6[2.1-6.5]$ & \\
\hline & & & & & & & rs7588295 & CSRNP3 & 2 & 6.24E-06 & $8.6[3.3-22.17]$ & \\
\hline & & & & & & & rs4431170 & $M A R C H 1$ & 4 & 7.28E-06 & $5.1[2.5-10.6]$ & \\
\hline & & & & & & & rs7740004 & C6orf170 & 6 & 7.87E-06 & $5.9[2.7-13.0]$ & \\
\hline & & & & & & & rs11189381 & SFRP5 & 10 & 8.17E-06 & $6.8[2.9-15.8]$ & \\
\hline & & & & & & & rs12903202 & ALDH1A2 & 15 & $9.15 \mathrm{E}-06$ & $4.0[2.1-7.4]$ & \\
\hline & & & & & & & rs17751934 & MEXЗС & 18 & $9.16 \mathrm{E}-06$ & $5.0[2.4-10.1]$ & \\
\hline & & & & & & & $\begin{array}{c}11- \\
23990403\end{array}$ & LUZP2 & 11 & 9.94E-06 & $12.7[4.0-36.8]$ & \\
\hline
\end{tabular}




\begin{tabular}{|c|c|c|c|c|c|c|c|c|c|c|c|c|}
\hline Year & Population & $\begin{array}{c}\text { Underlying } \\
\text { disease }\end{array}$ & BPs type & $\begin{array}{c}\text { Case } \\
n\end{array}$ & $\begin{array}{c}\text { Control } \\
n\end{array}$ & Genotyping & SNP & Gene & Chr & $\begin{array}{c}p \text { - } \\
\text { value }\end{array}$ & OR $[95 \% \mathrm{Cl}]$ & Ref \\
\hline 2010 & $\begin{array}{c}80 \% \\
\text { Caucasian } \\
10 \% \\
\text { African } \\
\text { American }\end{array}$ & $\begin{array}{l}\text { Prostate } \\
\text { cancer }\end{array}$ & $\begin{array}{l}\text { Zoledronate } \\
\text { Combination } \\
\text { of BPs }\end{array}$ & 17 & $\begin{array}{l}83 \mathrm{BPs} \\
\text { controls }\end{array}$ & $\begin{array}{c}\text { Big Dye } \\
\text { Terminator } \\
\text { Cycle } \\
\text { Sequencing } \\
\text { Ready Reaction } \\
\text { kit V3.1 }\end{array}$ & rs1934951 & CYP2C8 & 10 & $>0.47$ & $0.63[0.17-2.42]$ & [22] \\
\hline 2011 & $\begin{array}{c}68 \% \text { White } \\
24 \% \\
\text { African } \\
\text { American } \\
\end{array}$ & $\begin{array}{l}\text { Multiple } \\
\text { myeloma }\end{array}$ & $\begin{array}{l}\text { Zoledronate } \\
\text { and/or } \\
\text { Pamidronate }\end{array}$ & 12 & $\begin{array}{l}66 \mathrm{BPs} \\
\text { controls }\end{array}$ & $\begin{array}{c}\text { Taqman® } \\
\text { Pyrosequencing }\end{array}$ & $\begin{array}{l}\text { rs1934951 } \\
\text { rs1934980 }\end{array}$ & $\begin{array}{l}\text { CYP2C8 } \\
\text { CYP2C8 }\end{array}$ & $\begin{array}{l}10 \\
10\end{array}$ & $\begin{array}{l}0.63 \\
0.66\end{array}$ & $\begin{array}{l}0.68[0.14-3.22] \\
0.70[0.15-3.36]\end{array}$ & [23] \\
\hline 2011 & Caucasian & $\begin{array}{l}\text { Multiple } \\
\text { myeloma }\end{array}$ & Zoledronate & 42 & $\begin{array}{c}37 \text { BPs } \\
\text { controls } \\
45 \\
45 \\
\text { population } \\
\text { controls }\end{array}$ & Taqman® & rs1934951 & CYP2C8 & 10 & 0.13 & l & [27] \\
\hline 2012 & Hungarian & $\begin{array}{c}\text { Breast } \\
\text { cancer } \\
\text { Osteoporosis } \\
\text { Multiple } \\
\text { myeloma } \\
\text { Prostate } \\
\text { cancer }\end{array}$ & $\begin{array}{l}\text { Zoledronate } \\
\text { Ibandronate } \\
\text { Pamidronate }\end{array}$ & 46 & $\begin{array}{c}224 \\
\text { population } \\
\text { controls }\end{array}$ & Taqman® & rs1934951 & CYP2C8 & 10 & $>0.05$ & l & [30] \\
\hline
\end{tabular}


Table 3. Summary of discovery candidate gene studies

\begin{tabular}{|c|c|c|c|c|c|c|c|c|c|c|c|c|}
\hline Year & $\begin{array}{c}\text { Populatio } \\
n\end{array}$ & $\begin{array}{l}\text { Underlying } \\
\text { disease }\end{array}$ & BPs type & $\begin{array}{c}\text { Case } \\
n\end{array}$ & $\underset{n}{\text { Control }}$ & Genotyping & SNP & Gene & Chr & $p$-value & OR [95\% Cl] & Ref \\
\hline \multirow{8}{*}{2011} & \multirow{8}{*}{$\begin{array}{c}68 \% \text { White } \\
24 \% \\
\text { African } \\
\text { American }\end{array}$} & \multirow{8}{*}{ MM } & \multirow{8}{*}{$\begin{array}{c}\text { ZOL } \\
\text { and/or PM }\end{array}$} & \multirow{8}{*}{12} & \multirow{8}{*}{$\begin{array}{l}66 \mathrm{BPs} \\
\text { controls }\end{array}$} & \multirow{8}{*}{$\begin{array}{c}\text { Taqman® } \\
\text { Pyrosequencin } \\
\mathrm{g}\end{array}$} & rs1800012 & COL1A1 & 17 & 0.55 & $1.69[0.30-9.70]$ & \multirow{8}{*}{ [23] } \\
\hline & & & & & & & rs12458117 & $R A N K$ & 18 & 0.38 & $2.14[0.39-11.71]$ & \\
\hline & & & & & & & rs243865 & MMP2 & 16 & 0.11 & $3.49[0.75-16.18]$ & \\
\hline & & & & & & & rs2073618 & $O P G$ & 8 & 0.38 & $2.16[0.38-12.23]$ & \\
\hline & & & & & & & rs3102735 & $O P G$ & 8 & 0.75 & $0.79[0.19-3.34]$ & \\
\hline & & & & & & & rs11730582 & $O P N$ & 4 & 0.21 & $2.97[0.53-16.55]$ & \\
\hline & & & & & & & rs28357094 & OPN & 4 & 0.41 & $0.51[0.10-2.59]$ & \\
\hline & & & & & & & rs1800629 & $T N F$ & 6 & 0.67 & 0.68 [0.12-3.95] & \\
\hline \multirow{3}{*}{2011} & \multirow{3}{*}{ Italian } & \multirow{3}{*}{$\mathrm{BC}, \mathrm{MM}$} & \multirow{3}{*}{ ZOL } & \multirow{3}{*}{30} & \multirow{3}{*}{$\begin{array}{c}30 \mathrm{BPs} \\
\text { controls; } \\
125 \\
\text { population } \\
\text { controls } \\
\end{array}$} & \multirow{3}{*}{ Taqman® } & rs3025039 & \multirow{3}{*}{ VEGF } & \multirow{3}{*}{6} & 0.40 & $0.57[0.21-1.54]$ & \multirow{3}{*}{ [24] } \\
\hline & & & & & & & rs699947 & & & 0.78 & $0.99[0.31-3.18]$ & \\
\hline & & & & & & & rs2010963 & & & 0.86 & 0.96 [0.37-2.53] & \\
\hline \multirow{8}{*}{2011} & \multirow{8}{*}{$\mathrm{N} / \mathrm{A}$} & \multirow{8}{*}{ MM } & \multirow{8}{*}{ ZOL } & \multirow{8}{*}{9} & \multirow{8}{*}{$\begin{array}{l}10 \mathrm{BPs} \\
\text { controls }\end{array}$} & \multirow{8}{*}{$\begin{array}{l}\text { Affymetrix } \\
\text { DMET TM plus }^{\text {TM }} \\
\text { platform } \\
1,936 \text { SNPs } \\
\text { analysed }\end{array}$} & rs1152003 & PPARG & 3 & 0.0055 & \multirow{8}{*}{ I } & \multirow{8}{*}{ [25] } \\
\hline & & & & & & & rs10893 & & & 0.023 & & \\
\hline & & & & & & & rs4725373 & $A B P 1$ & 7 & 0.023 & & \\
\hline & & & & & & & rs1049793 & & & 0.023 & & \\
\hline & & & & & & & rs2463437 & & & 0.0198 & & \\
\hline & & & & & & & rs903247 & CHST11 & 12 & 0.0198 & & \\
\hline & & & & & & & rs2468110 & & & 0.0198 & & \\
\hline & & & & & & & rs2097937 & CROT & 7 & 0.0198 & & \\
\hline 2011 & Caucasian & $\begin{array}{l}\text { BC, MM, } \\
\text { PC }\end{array}$ & ZOL & 34 & $\begin{array}{l}34 \mathrm{BPs} \\
\text { controls }\end{array}$ & GoTaq® & rs2297480 & FDPS & 1 & 0.03 & / & [26] \\
\hline \multirow{3}{*}{2012} & \multirow{3}{*}{ Caucasian } & & & & & & rs2234693 & ESR1 & 6 & $>0.05$ & 1 & \\
\hline & & $\begin{array}{l}\text { BC, MM, } \\
\text { PC }\end{array}$ & ZOL & 30 & $\begin{array}{l}53 \text { BPs } \\
\text { controls }\end{array}$ & Taqman® & rs9340799 & ESR1 & 6 & $>0.05$ & 1 & [29] \\
\hline & & & & & & & rs10046 & CYP19A1 & 15 & 0.0439 & 2.83 & \\
\hline & & & & & & & DRB1*01 & & & 0.049 & $2.0[0.99-4.1]$ & \\
\hline 2013 & & $\mathrm{BC}, \mathrm{MM}$ & or & & $110 \mathrm{BPs}$ & single strand & DRB1*15 & $M H C$ & & 0.014 & $2.3[1.2-4.4]$ & \\
\hline 2013 & VVnite & PC & Combination & 94 & controls & oligonucleotide & DQB1*05:01 & NIHC & b & 0.050 & $2.0[0.99-4.0]$ & [31] \\
\hline & & & & & & typıng kIt & DQB1 ${ }^{*} 06: 02$ & & & 0.014 & $2.3[1.2-4.6]$ & \\
\hline
\end{tabular}

BC: Breast cancer; MM: Multiple myeloma; PC: Prostate cancer; ZOL: Zoledronate; PM: Pamidronate 


\section{References}

[1] S. L. Ruggiero, T. B. Dodson, J. Fantasia, R. Goodday, T. Aghaloo, B. Mehrotra,

F. O'Ryan, and American Association of Oral and Maxillofacial Surgeons, "American Association of Oral and Maxillofacial Surgeons position paper on medication-related osteonecrosis of the jaw--2014 update," J. Oral Maxillofac. Surg. Off. J. Am. Assoc. Oral Maxillofac. Surg., vol. 72, no. 10, pp. 1938-1956, Oct. 2014.

[2] S. Cremers and S. Papapoulos, "Pharmacology of bisphosphonates," Bone, vol. 49, no. 1, pp. 42-49, Jul. 2011.

[3] R. G. G. Russell, "Bisphosphonates: mode of action and pharmacology," Pediatrics, vol. 119 Suppl 2, pp. S150-162, Mar. 2007.

[4] R. G. G. Russell, "Bisphosphonates: The first 40years," Bone, vol. 49, no. 1, pp. 2-19, Jul. 2011.

[5] M. J. Rogers, J. C. Crockett, F. P. Coxon, and J. Mönkkönen, "Biochemical and molecular mechanisms of action of bisphosphonates," Bone, vol. 49, no. 1, pp. 3441, Jul. 2011.

[6] R. E. Marx, "Pamidronate (Aredia) and zoledronate (Zometa) induced avascular necrosis of the jaws: a growing epidemic," J. Oral Maxillofac. Surg. Off. J. Am. Assoc. Oral Maxillofac. Surg., vol. 61, no. 9, pp. 1115-1117, Sep. 2003.

[7] O. Filleul, E. Crompot, and S. Saussez, "Bisphosphonate-induced osteonecrosis of the jaw: a review of 2,400 patient cases," J. Cancer Res. Clin. Oncol., vol. 136, no. 8, pp. 1117-1124, May 2010.

[8] P. Sambrook, I. Olver, and A. Goss, "Bisphosphonates and osteonecrosis of the jaw," Aust. Fam. Physician, vol. 35, no. 10, pp. 801-803, Oct. 2006.

[9] S. Khosla, D. Burr, J. Cauley, D. W. Dempster, P. R. Ebeling, D. Felsenberg, R.

F. Gagel, V. Gilsanz, T. Guise, S. Koka, L. K. McCauley, J. McGowan, M. D. McKee, 
S. Mohla, D. G. Pendrys, L. G. Raisz, S. L. Ruggiero, D. M. Shafer, L. Shum, S. L. Silverman, C. H. Van Poznak, N. Watts, S.-B. Woo, and E. Shane, "Bisphosphonateassociated osteonecrosis of the jaw: report of a task force of the American Society for Bone and Mineral Research," J. Bone Miner. Res. Off. J. Am. Soc. Bone Miner. Res., vol. 22, no. 10, pp. 1479-1491, Oct. 2007.

[10] S. L. Ruggiero, T. B. Dodson, L. A. Assael, R. Landesberg, R. E. Marx, and B. Mehrotra, "American Association of Oral and Maxillofacial Surgeons position paper on bisphosphonate-related osteonecrosis of the jaws--2009 update," J. Oral Maxillofac. Surg. Off. J. Am. Assoc. Oral Maxillofac. Surg., vol. 67, no. 5 Suppl, pp. 2-12, May 2009.

[11] S. Fedele, S. R. Porter, F. D’Aiuto, S. Aljohani, P. Vescovi, M. Manfredi, P. G. Arduino, R. Broccoletti, A. Musciotto, O. Di Fede, T. S. Lazarovici, G. Campisi, and N. Yarom, "Nonexposed variant of bisphosphonate-associated osteonecrosis of the jaw: a case series," Am. J. Med., vol. 123, no. 11, pp. 1060-1064, Nov. 2010. [12] A. Bedogni, V. Fusco, A. Agrillo, and G. Campisi, "Learning from experience. Proposal of a refined definition and staging system for bisphosphonate-related osteonecrosis of the jaw (BRONJ)," Oral Dis., vol. 18, no. 6, pp. 621-623, Sep. 2012.

[13] S. Fedele, G. Bedogni, M. Scoletta, G. Favia, G. Colella, A. Agrillo, G. Bettini, O. Di Fede, G. Oteri, V. Fusco, M. Gabriele, L. Ottolenghi, S. Valsecchi, S. Porter, P. P.-L. Fung, G. Saia, G. Campisi, and A. Bedogni, "Up to a quarter of patients with osteonecrosis of the jaw associated with antiresorptive agents remain undiagnosed," Br. J. Oral Maxillofac. Surg., vol. 53, no. 1, pp. 13-17, Jan. 2015.

[14] J. V. Bagan, E. Hens-Aumente, M. Leopoldo-Rodado, R. Poveda-Roda, and L. Bagan, "Bisphosphonate-related osteonecrosis of the jaws: Study of the staging 
system in a series of clinical cases," Oral Oncol., vol. 48, no. 8, pp. 753-757, Aug. 2012.

[15] R. A. Miksad, K.-C. Lai, T. B. Dodson, S.-B. Woo, N. S. Treister, O. Akinyemi, M. Bihrle, G. Maytal, M. August, G. S. Gazelle, and J. S. Swan, "Quality of Life Implications of Bisphosphonate-Associated Osteonecrosis of the Jaw," The Oncologist, vol. 16, no. 1, pp. 121 -132, Jan. 2011.

[16] S. Kühl, C. Walter, S. Acham, R. Pfeffer, and J. T. Lambrecht, "Bisphosphonate-related osteonecrosis of the jaws--a review," Oral Oncol., vol. 48, no. 10, pp. 938-947, Oct. 2012.

[17] R. Landesberg, V. Woo, S. Cremers, M. Cozin, D. Marolt, G. VunjakNovakovic, S. Kousteni, and S. Raghavan, "Potential pathophysiological mechanisms in osteonecrosis of the jaw," Ann. N. Y. Acad. Sci., vol. 1218, pp. 6279, Feb. 2011.

[18] M. R. Allen, "The effects of bisphosphonates on jaw bone remodeling, tissue properties, and extraction healing," Odontol. Soc. Nippon Dent. Univ., vol. 99, no. 1, pp. 8-17, Jan. 2011.

[19] A. A. Khan, G. K. B. Sándor, E. Dore, A. D. Morrison, M. Alsahli, F. Amin, E. Peters, D. A. Hanley, S. R. Chaudry, B. Lentle, D. W. Dempster, F. H. Glorieux, A. J. Neville, R. M. Talwar, C. M. Clokie, M. A. Mardini, T. Paul, S. Khosla, R. G. Josse, S. Sutherland, D. K. Lam, R. P. Carmichael, N. Blanas, D. Kendler, S. Petak, L. G. SteMarie, J. Brown, A. W. Evans, L. Rios, and J. E. Compston, "Bisphosphonate associated osteonecrosis of the jaw," J. Rheumatol., vol. 36, no. 3, pp. 478-490, Mar. 2009. 
[20] K. A. Phillips, D. L. Veenstra, E. Oren, J. K. Lee, and W. Sadee, "Potential role of pharmacogenomics in reducing adverse drug reactions: a systematic review," JAMA, vol. 286, no. 18, pp. 2270-2279, Nov. 2001.

[21] M. E. Sarasquete, R. García-Sanz, L. Marín, M. Alcoceba, M. C. Chillón, A. Balanzategui, C. Santamaria, L. Rosiñol, J. de la Rubia, M. T. Hernandez, I. GarciaNavarro, J. J. Lahuerta, M. González, and J. F. San Miguel, "Bisphosphonate-related osteonecrosis of the jaw is associated with polymorphisms of the cytochrome P450 CYP2C8 in multiple myeloma: a genome-wide single nucleotide polymorphism analysis," Blood, vol. 112, no. 7, pp. 2709-2712, Oct. 2008.

[22] B. C. English, C. E. Baum, D. E. Adelberg, T. M. Sissung, P. G. Kluetz, W. L. Dahut, D. K. Price, and W. D. Figg, "A SNP in CYP2C8 is not associated with the development of bisphosphonate-related osteonecrosis of the jaw in men with castrate-resistant prostate cancer," Ther. Clin. Risk Manag., vol. 6, pp. 579-583, 2010.

[23] J. Katz, Y. Gong, D. Salmasinia, W. Hou, B. Burkley, P. Ferreira, O. Casanova, T. Y. Langaee, and J. S. Moreb, "Genetic polymorphisms and other risk factors associated with bisphosphonate induced osteonecrosis of the jaw," Int. J. Oral Maxillofac. Surg., vol. 40, no. 6, pp. 605-611, Jun. 2011.

[24] P. G. Arduino, E. Menegatti, M. Scoletta, C. Battaglio, M. Mozzati, A. Chiecchio, D. Berardi, A. M. Vandone, M. Donadio, S. Gandolfo, C. Scully, and R. Broccoletti, "Vascular endothelial growth factor genetic polymorphisms and haplotypes in female patients with bisphosphonate-related osteonecrosis of the jaws," J. Oral Pathol. Med. Off. Publ. Int. Assoc. Oral Pathol. Am. Acad. Oral Pathol., vol. 40, no. 6, pp. 510-515, Jul. 2011. 
[25] M. T. Di Martino, M. Arbitrio, P. H. Guzzi, E. Leone, F. Baudi, E. Piro, T.

Prantera, I. Cucinotto, T. Calimeri, M. Rossi, P. Veltri, M. Cannataro, P. Tagliaferri, and $P$. Tassone, "A peroxisome proliferator-activated receptor gamma (PPARG) polymorphism is associated with zoledronic acid-related osteonecrosis of the jaw in multiple myeloma patients: analysis by DMET microarray profiling," Br. J. Haematol., vol. 154, no. 4, pp. 529-533, Aug. 2011.

[26] F. Marini, P. Tonelli, L. Cavalli, T. Cavalli, L. Masi, A. Falchetti, and M. L. Brandi, "Pharmacogenetics of bisphosphonate-associated osteonecrosis of the jaw," Front. Biosci. Elite Ed., vol. 3, pp. 364-370, 2011.

[27] E. Such, J. Cervera, E. Terpos, J. V. Bagán, A. Avaria, I. Gómez, M. Margaix, M. Ibañez, I. Luna, L. Cordón, M. Roig, M. A. Sanz, M. A. Dimopoulos, and J. de la Rubia, "CYP2C8 gene polymorphism and bisphosphonate-related osteonecrosis of the jaw in patients with multiple myeloma," Haematologica, vol. 96, no. 10, pp. 15571559, Oct. 2011.

[28] P. Nicoletti, V. M. Cartsos, P. K. Palaska, Y. Shen, A. Floratos, and A. I. Zavras, "Genomewide pharmacogenetics of bisphosphonate-induced osteonecrosis of the jaw: the role of RBMS3," The oncologist, vol. 17, no. 2, pp. 279-287, 2012. [29] F. La Ferla, E. Paolicchi, F. Crea, S. Cei, F. Graziani, M. Gabriele, and R. Danesi, "An aromatase polymorphism (g.132810C>T) predicts risk of bisphosphonate-related osteonecrosis of the jaw," Biomark. Med., vol. 6, no. 2, pp. 201-209, Apr. 2012.

[30] B. Balla, M. Vaszilko, J. P. Kósa, J. Podani, I. Takács, B. Tóbiás, Z. Nagy, A. Lazáry, and P. Lakatos, "New approach to analyze genetic and clinical data in bisphosphonate-induced osteonecrosis of the jaw," Oral Dis., vol. 18, no. 6, pp. 580585, Sep. 2012. 
Rauh, M. W. Beckmann, P. A. Fasching, T. Kreusch, A. Mackensen, B. Wullich, G. Schett, and B. M. Spriewald, "Major histocompatibility complex class II polymorphisms are associated with the development of anti-resorptive agent-induced osteonecrosis of the jaw," J. Cranio-Maxillo-fac. Surg. Off. Publ. Eur. Assoc. CranioMaxillo-fac. Surg., vol. 41, no. 1, pp. 71-75, Jan. 2013.

[32] A. D. Roses, "Pharmacogenetics and the practice of medicine," Nature, vol. 405, no. 6788, pp. 857-865, Jun. 2000.

[33] M. McCormack, A. Alfirevic, S. Bourgeois, J. J. Farrell, D. Kasperavičiūtè, M. Carrington, G. J. Sills, T. Marson, X. Jia, P. I. W. de Bakker, K. Chinthapalli, M. Molokhia, M. R. Johnson, G. D. O'Connor, E. Chaila, S. Alhusaini, K. V. Shianna, R. A. Radtke, E. L. Heinzen, N. Walley, M. Pandolfo, W. Pichler, B. K. Park, C. Depondt, S. M. Sisodiya, D. B. Goldstein, P. Deloukas, N. Delanty, G. L. Cavalleri, and M. Pirmohamed, "HLA-A*3101 and carbamazepine-induced hypersensitivity reactions in Europeans," N. Engl. J. Med., vol. 364, no. 12, pp. 1134-1143, Mar. 2011.

[34] W.-H. Chung, S.-I. Hung, H.-S. Hong, M.-S. Hsih, L.-C. Yang, H.-C. Ho, J.-Y. Wu, and Y.-T. Chen, "Medical genetics: a marker for Stevens-Johnson syndrome," Nature, vol. 428, no. 6982, p. 486, Apr. 2004.

[35] E. Link, S. Parish, J. Armitage, L. Bowman, S. Heath, F. Matsuda, I. Gut, M. Lathrop, and R. Collins, "SLCO1B1 variants and statin-induced myopathy--a genomewide study," N. Engl. J. Med., vol. 359, no. 8, pp. 789-799, Aug. 2008. [36] S. Mallal, D. Nolan, C. Witt, G. Masel, A. M. Martin, C. Moore, D. Sayer, A. Castley, C. Mamotte, D. Maxwell, I. James, and F. T. Christiansen, "Association between presence of HLA-B*5701, HLA-DR7, and HLA-DQ3 and hypersensitivity to 
HIV-1 reverse-transcriptase inhibitor abacavir," Lancet, vol. 359, no. 9308, pp. 727732, Mar. 2002.

[37] S. Hetherington, A. R. Hughes, M. Mosteller, D. Shortino, K. L. Baker, W. Spreen, E. Lai, K. Davies, A. Handley, D. J. Dow, M. E. Fling, M. Stocum, C.

Bowman, L. M. Thurmond, and A. D. Roses, "Genetic variations in HLA-B region and hypersensitivity reactions to abacavir," Lancet, vol. 359, no. 9312, pp. 1121-1122, Mar. 2002.

[38] A. K. Daly, P. T. Donaldson, P. Bhatnagar, Y. Shen, I. Pe'er, A. Floratos, M. J. Daly, D. B. Goldstein, S. John, M. R. Nelson, J. Graham, B. K. Park, J. F. Dillon, W. Bernal, H. J. Cordell, M. Pirmohamed, G. P. Aithal, and C. P. Day, "HLA-B`5701 genotype is a major determinant of drug-induced liver injury due to flucloxacillin," Nat. Genet., vol. 41, no. 7, pp. 816-819, Jul. 2009.

[39] A. K. Daly, "Pharmacogenomics of adverse drug reactions," Genome Med., vol. 5, no. 1, p. 5, 2013.

[40] J. B. Singer, S. Lewitzky, E. Leroy, F. Yang, X. Zhao, L. Klickstein, T. M. Wright, J. Meyer, and C. A. Paulding, "A genome-wide study identifies HLA alleles associated with lumiracoxib-related liver injury," Nat. Genet., vol. 42, no. 8, pp. $711-$ 714, Aug. 2010.

[41] S. Mallal, E. Phillips, G. Carosi, J.-M. Molina, C. Workman, J. Tomazic, E. Jägel-Guedes, S. Rugina, O. Kozyrev, J. F. Cid, P. Hay, D. Nolan, S. Hughes, A. Hughes, S. Ryan, N. Fitch, D. Thorborn, A. Benbow, and PREDICT-1 Study Team, "HLA-B`5701 screening for hypersensitivity to abacavir," N. Engl. J. Med., vol. 358, no. 6 , pp. 568-579, Feb. 2008.

[42] S. G. Leckband, J. R. Kelsoe, H. M. Dunnenberger, A. L. George, E. Tran, R. Berger, D. J. Müller, M. Whirl-Carrillo, K. E. Caudle, M. Pirmohamed, and Clinical 
Pharmacogenetics Implementation Consortium, "Clinical Pharmacogenetics Implementation Consortium guidelines for HLA-B genotype and carbamazepine dosing," Clin. Pharmacol. Ther., vol. 94, no. 3, pp. 324-328, Sep. 2013.

[43] M. A. Hamburg and F. S. Collins, "The Path to Personalized Medicine," N. Engl. J. Med., vol. 363, no. 4, pp. 301-304, 2010.

[44] A. K. Daly, "Genome-wide association studies in pharmacogenomics," Nat. Rev. Genet., vol. 11, no. 4, pp. 241-246, Apr. 2010.

[45] A. K. Daly, "Using genome-wide association studies to identify genes important in serious adverse drug reactions," Annu. Rev. Pharmacol. Toxicol., vol. 52, pp. 21-35, Feb. 2012.

[46] A. D. Roses, "Pharmacogenetics and the practice of medicine," Nature, vol. 405, no. 6788, pp. 857-865, Jun. 2000.

[47] M. E. Sarasquete, M. González, J. F. San Miguel, and R. García-Sanz, "Bisphosphonate-related osteonecrosis: genetic and acquired risk factors," Oral Dis., vol. 15, no. 6, pp. 382-387, Sep. 2009.

[48] W. S. Bush and J. H. Moore, "Chapter 11: Genome-wide association studies," PLoS Comput. Biol., vol. 8, no. 12, p. e1002822, 2012.

[49] M. I. McCarthy, G. R. Abecasis, L. R. Cardon, D. B. Goldstein, J. Little, J. P. A. Ioannidis, and J. N. Hirschhorn, "Genome-wide association studies for complex traits: consensus, uncertainty and challenges," Nat. Rev. Genet., vol. 9, no. 5, pp. 356-369, May 2008.

[50] A. K. Daly and C. P. Day, "Candidate gene case-control association studies: advantages and potential pitfalls," Br. J. Clin. Pharmacol., vol. 52, no. 5, pp. 489499, Nov. 2001. 
[51] H. K. Tabor, N. J. Risch, and R. M. Myers, "Candidate-gene approaches for studying complex genetic traits: practical considerations," Nat. Rev. Genet., vol. 3, no. 5, pp. 391-397, May 2002.

[52] P. Kraft, E. Zeggini, and J. P. A. Ioannidis, "Replication in genome-wide association studies," Stat. Sci. Rev. J. Inst. Math. Stat., vol. 24, no. 4, pp. 561-573, Nov. 2009.

[53] D.-N. Zhong, J.-Z. Wu, and G.-J. Li, "Association between CYP2C8 (rs1934951) polymorphism and bisphosphonate-related osteonecrosis of the jaws in patients on bisphosphonate therapy: a meta-analysis," Acta Haematol., vol. 129, no. 2, pp. 90-95, 2013.

[54] T.-H. Kim, J. M. Hong, J.-Y. Lee, B. Oh, E. K. Park, C.-K. Lee, S.-C. Bae, and S.-Y. Kim, "Promoter polymorphisms of the vascular endothelial growth factor gene is associated with an osteonecrosis of the femoral head in the Korean population," Osteoarthr. Cartil. OARS Osteoarthr. Res. Soc., vol. 16, no. 3, pp. 287-291, Mar. 2008.

[55] Y. J. Lee, J. S. Lee, E. H. Kang, Y.-K. Lee, S.-Y. Kim, Y. W. Song, and K.-H. Koo, "Vascular endothelial growth factor polymorphisms in patients with steroidinduced femoral head osteonecrosis," J. Orthop. Res. Off. Publ. Orthop. Res. Soc., vol. 30, no. 1, pp. 21-27, Jan. 2012.

[56] T. K. Rice, N. J. Schork, and D. C. Rao, "Methods for Handling Multiple Testing," Genet. Dissection Complex Traits 2nd Ed., vol. 60, pp. 293-308, 2008. 